\title{
Promoting equity in retreat through voluntary property buyout programs
}

\author{
Caroline M. Kraan ${ }^{1}$ (D) $\cdot$ Miyuki Hino ${ }^{2,3}$ (D) Jennifer Niemann ${ }^{4,5}$ (D) A. R. Siders ${ }^{6,7}$ (i) Katharine J. Mach $^{4,5}$ (D)
}

Accepted: 22 April 2021 / Published online: 11 May 2021

(C) The Author(s) 2021

\begin{abstract}
Voluntary property buyouts have been the most prevalent form of managed retreat in the USA to date. Tens of thousands of households have sold their flood-prone homes to the government, and after the structures are demolished, the land becomes open space. Concerns have been raised about the equity of buyout processes and outcomes, spanning distributive, procedural, and interactional dimensions of social justice. In this policy analysis, we first provide an overview of equity and justice issues in buyouts based on existing literature. We consider multiple relevant stakeholder groups: the communities in which buyouts occur, potential participants and relocating households, residents who choose to stay, and the destination communities. Second, we present policy options that may address and reduce existing social inequities in buyouts. Third, we outline how improved reporting on buyout programs by implementers can support buyout policy learning that will improve buyout outcomes and equity. Indicators can provide insight on who has access to buyouts, the effect of buyout implementation on outcomes, and the consequences of relocating — or not—-for all affected. With increasing climate risks, voluntary property buyouts will remain an important means of reducing exposure to flooding and other hazards. For this method of retreat to occur effectively at greater scale, attention to social justice in program evaluation and policy learning is necessary.
\end{abstract}

Keywords Buyouts $\cdot$ Managed retreat $\cdot$ Equity $\cdot$ Flood hazard mitigation $\cdot$ Social justice

By 2100 in the USA, coastal population growth and sea level rise could put between 4 and 13 million people at risk of

Caroline M. Kraan

ckraan@miami.edu

1 Environmental Science and Policy Graduate Program, Leonard and Jayne Abess Center for Ecosystem Science and Policy, University of Miami, Coral Gables, FL, USA

2 Department of City and Regional Planning, University of North Carolina at Chapel Hill, Chapel Hill, NC, USA

3 Environment, Ecology, and Energy Program, University of North Carolina at Chapel Hill, Chapel Hill, NC, USA

4 Rosenstiel School of Marine and Atmospheric Science, University of Miami, Miami, FL, USA

5 Leonard and Jayne Abess Center for Ecosystem Science and Policy, University of Miami, Coral Gables, FL, USA

6 Disaster Research Center, University of Delaware, Newark, DE, USA

7 Biden School of Public Policy and Administration and Department of Geography and Spatial Sciences, University of Delaware, Newark, DE, USA inundation (Hauer et al. 2016). The financial, techno-economic, and ecological challenges of armoring the entirety of the US coastline mean retreat will become unavoidable in some places (Jay et al. 2018; Lincke and Hinkel 2018). Managed retreat, the purposeful relocation of people and infrastructure out of hazardous areas, is likely to play an increasingly important role in responses to sea level rise and flood risk. Although future retreat may take several forms, including community relocation and land use regulations, most retreat in the USA to date has been conducted through voluntary property buyouts (Mach et al. 2019; Marino 2018).

In most buyout programs, owners sell their flood-prone properties to the government, structures are removed, and the land is then maintained as open space. Buyouts are primarily intended to reduce flood risk and government liability for future disaster damages and recovery. Tens of thousands of households across the nation have relocated through buyout programs, often in post-disaster contexts (Braamskamp and Penning-Rowsell 2018; Mach et al. 2019). However, concerns have been raised about the equity of buyout processes and outcomes (Baker et al. 2018; Gotham 2014; Mach et al. 2019; Muñoz and Tate 2016; Siders 2019). The links among 
environment, climate, and justice are unavoidable (Bullard and Johnson 2000; Schlosberg 2012; Schlosberg and Collins 2014; Shue 1992). There are many complementary concepts of social justice related to fairness, equality, or equity among members of a society (Adger et al. 2006). We focus on three dimensions of social justice: (a) distributive, concerning fairness in how costs and benefits are shared within a community or society (Rawls 1971); (b) procedural, concerning fairness and inclusion in decision-making processes (Schlosberg and Collins 2014); and (c) interactional, concerning the quality of interpersonal treatment people receive throughout a process (Folger 1996). Although these are by no means the only dimensions of justice, they are the ones most aligned with the literature on voluntary property buyout programs, as we survey and critique below. Other dimensions of justice, such as ecological, recognition, restorative, capabilities, and intergenerational justice, are relevant but to date have been largely absent from discussions about buyout programs (Siders 2019).

In this policy analysis, we present several policy options that are intended to promote equity in buyout programs. First, we review justice concerns in the buyout literature for four distinct, yet overlapping, stakeholder groups affected by buyouts: the wider communities in which buyouts may occur, potential participants and relocating households, households remaining in buyout communities, and destination communities where buyout participants relocate. For each of these stakeholder groups, we critique relevant literature through the lens of distributive, procedural, and interactional justice. Second, drawing on the existing literature across disciplines, we synthesize available evidence about strategies for improving justice and suggest additional policy options that could be relevant in some contexts. No comprehensive overview of strategies to proactively promote social justice in buyout programs currently exists, so this compilation is intended to provide a synthesis of policy options for practitioners and analysts. Third, based on existing evaluations of buyouts and other disaster and adaptation strategies, we outline a range of entry points for improved data reporting in buyout programs to allow for better assessment and evaluation of social justice and equity, which can support the development of additional strategies to improve equity in buyout programs. To date, successive buyout programs occurring over decades and across many different communities in the USA have shown no significant policy changes or improvements, indicating little policy learning has taken place (Greer and Binder 2017). We argue that improved data collection and evaluation practices could enable lessons from past experiences with buyout programstheir funding mechanisms, policies, implementation, and outcomes - to improve future efforts. This structure of the policy analysis, enabling a process of policy learning, is illustrated in Fig. 1.

\section{Equity and social justice issues in voluntary property buyout programs}

Existing research has given rise to a number of distributive, procedural, and interactional justice concerns for a range of stakeholders. These social justice concerns arise at multiple points in time. In particular, concerns have been raised about the design and implementation phases of buyout programs, starting when a buyout program is initiated and ending when residents have relocated and structures are removed. Concerns have also been raised about the near-term outcomes and the longer-term impacts for residents and communities once buyouts are complete. The review of equity and justice issues in this section considers both the relevant stakeholder groups and the buyout phases in which concerns are raised.

\section{Communities in which buyouts may occur}

Where buyouts do and do not take place is a matter of distributive justice because of the positive and negative effects on participants and neighborhoods. Buyout programs can be funded through federal, state, and local governments, but most are designed and implemented by city or county governments (Mach et al. 2019). Local implementation predominates even when the federal government provides substantial funding, such as through the Federal Emergency Management Agency (FEMA) or the Department of Housing and Urban Development (HUD). Federal funding is often only available in post-disaster contexts, where a presidential disaster declaration has been issued. The decision to offer buyouts to households is predominantly made by local governments, who are balancing fiscal constraints, disaster recovery, and many other competing needs in their decision-making (BenDor et al. 2020). Local context and preferences, interacting with federal policies, influence which communities and property owners are offered buyouts and which households then accept these offers.

Jurisdictions that implement buyouts tend to be more urban and wealthier (Elliott et al. 2020; Mach et al. 2019). The government capacity and resources required to obtain funding and administer buyouts, and the higher value placed on open space in densely populated areas, may explain these patterns. However, despite wealthier jurisdictions more often administering buyouts, within those jurisdictions, buyouts usually occur in neighborhoods with relatively lower household incomes and more socially vulnerable populations (Elliott et al. 2020; Mach et al. 2019). Buyouts in racially diverse neighborhoods may be accepted most by white residents (Robinson et al. 2018), which could result in white flight in racially integrated neighborhoods (Loughran et al. 2019; Martin 2019). On the other hand, buyouts can also displace historic communities of color (Phillips et al. 2012). 


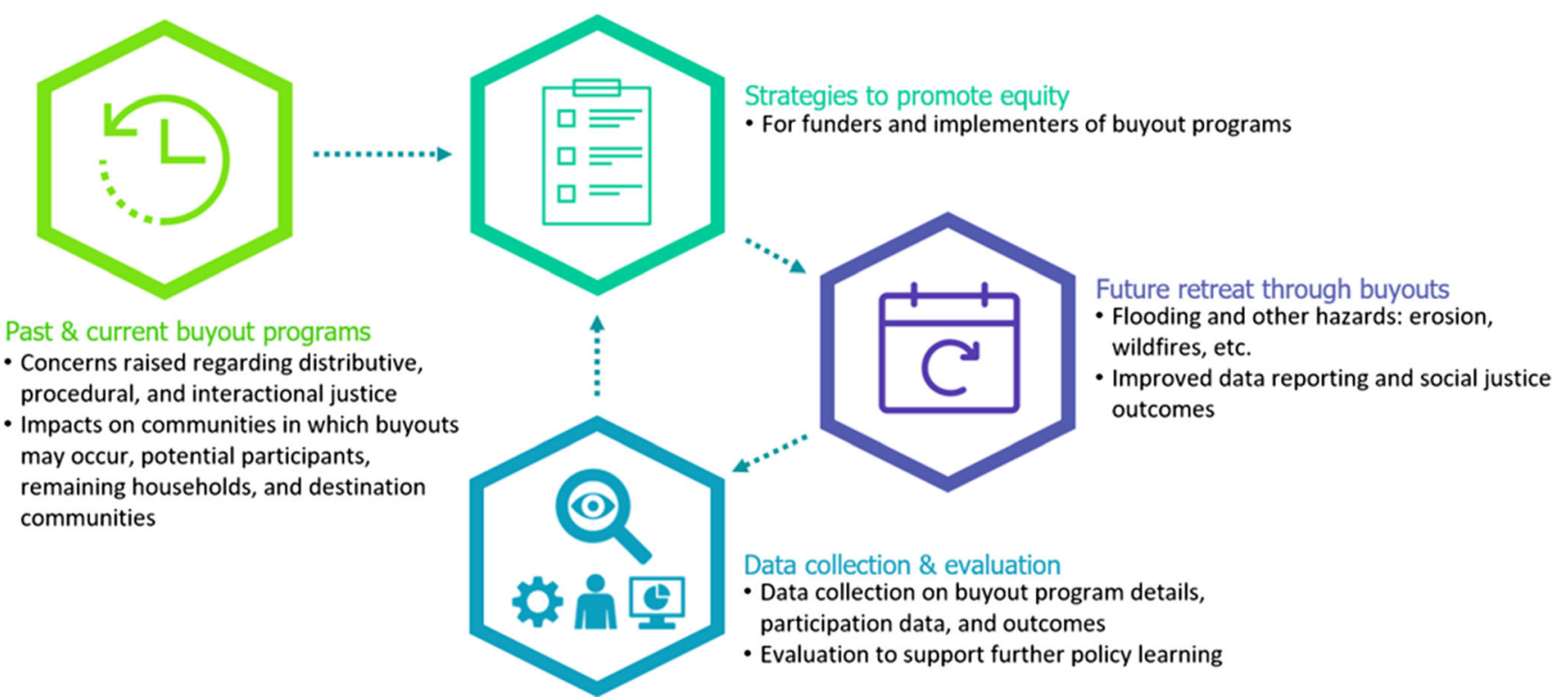

Fig. 1 Improvement of equity and social justice in voluntary property buyouts. Successive buyout programs in the USA show little policy learning. Evaluation to date results in a limited set of strategies that could promote social justice in future buyout programs. More

In addition to these concerns raised in the literature, decisions to not offer buyouts also raise questions concerning distributive justice (Siders 2019). Involuntary immobility can result when households would like access to buyouts but are not able to participate. Local governments may lack capacity, financial resources, or political will to administer a buyout program, or they may decide to target one neighborhood and not another. Residents in Staten Island, NY, were able to convince the state to administer a buyout program after Superstorm Sandy, after the local government was unwilling (Koslov 2016), but not all neighborhoods have sufficient political connections or community coordination to make their desires heard.

\section{Potential participants and relocating households}

Decisions about program design and implementation significantly affect the homeowner experience (Binder and Greer 2016; De Vries and Fraser 2012; Kick et al. 2011), and therefore perceptions of procedural justice about decisions made and interactional justice regarding the treatment of potential participants by buyout implementers.

Procedural justice concerns have been raised in buyout programs where communication or rationales behind decision-making are unclear, such as in the determination of the geographical boundaries for eligibility to participate (Binder and Greer 2016). Issues with fairness in decisionmaking processes also affect who participates. For example, a lack of trust between residents and buyout program officials can lead to non-participation (De Vries and Fraser 2012). transparent and comprehensive reporting of future program details, implementation processes, and post-buyout outcomes for different resident groups is necessary to support policy learning and promote equity in future buyout programs

A significant interactional justice concern is that not all residents experience buyout programs as fully voluntary, despite federal funding requirements for voluntary consent. Due to financial constraints, insistence from program officials, or limitations placed on rebuilding damaged homes, households can feel that accepting the buyout offer is effectively the only option they have (Binder and Greer 2016; De Vries and Fraser 2012; Green and Olshansky 2012; Greer and Binder 2017). Participation is certainly not voluntary for renters and some mobile home park residents, who may be effectively evicted when property owners or landowners agree to a buyout. A lower-bound estimate is that 4500 households have been affected this way through FEMA-funded buyouts since 1989 (FEMA 2020). Documentation about the experiences of these residents is virtually nonexistent.

Concerns about the lengthy, multi-year durations of buyout processes incorporate both procedural and interactional dimensions of justice (Binder and Greer 2016; De Vries and Fraser 2012; Mach et al. 2019; Muñoz and Tate 2016; Weber and Moore 2019). Homeowners might be more likely to accept buyout offers soon after the disaster, as shown by the significant drop in willingness of homeowners to participate after a few months post-Sandy on Staten Island (Purdy 2019). Slow buyouts may be onerous for low-income residents if they have to find alternate housing during the buyout process, which significantly increases their housing costs (Thomas 2019).

A number of distributive justice concerns have been raised about the compensation participants are offered for their properties. In the determination of buyout compensation and 
incentives, cost-benefit analyses limited to the most readily available market-based economic values (e.g., property values) can exacerbate existing inequalities (Gotham 2014). Homes that have damages totaling more than $50 \%$ of their property value are considered substantially damaged. In many programs, these homes are more likely to be eligible or targeted for buyouts. Lower value homes are more likely to be substantially damaged because, for a given flood severity or dollar value of damage, a lower-value home has relatively more damage than a higher-value home (Siders 2019). Additionally, in lower-income communities, appraisers have been found to be more likely to declare a home substantially damaged (De Vries and Fraser 2012). This might help lowerincome residents if they want to pursue a buyout, but it could also make them more likely to be displaced if the buyout is perceived as involuntary. Compensation to homeowners may also be affected by the speed of the buyout process. Because buyouts frequently take a long time to administer, many residents have few alternatives and choose to make repairs or rebuild their property (Baker et al. 2018). FEMA's duplication-of-benefits policy subtracts any federal assistance already granted to the household, including flood insurance payouts, from the final buyout offer, unless extensive documentation is provided by the property owner to justify the repair-related expenses (FEMA 2012). This policy leaves many households who made initial repairs on the property with fewer resources for relocation when disaster assistance or flood insurance claims are subtracted from the pre-disaster fair market value.

Assessment of distributive justice in buyout programs is limited because little is known about the social, economic, and other impacts of buyouts for potential participants (see also the "Data collection and evaluation" section). In buyout programs that have been assessed, households generally express satisfaction with having participated but also indicate frustration about the process and sadness over the loss of their sense of place or community (Baker et al. 2018; Binder et al. 2015; Fraser et al. 2003). One study that compared neighborhoods that offered buyouts to those that recovered in place found that place attachment and social capital were lower for buyout participants (Binder et al. 2019).

\section{Households remaining in buyout communities}

Buyout programs also raise distributive justice concerns for residents who remain in the neighborhood after buyout participants have relocated - whether by choice or because they were ineligible to participate in the buyout program - as they are affected by both the positive and the negative impacts associated with the change in land use. Under FEMA guidelines, land acquired through a buyout must be maintained as open space. Uses for the open space range from wetland restoration to athletic facilities and playgrounds (FEMA 2015).
However, many parcels are not repurposed but are merely left as vacant grass lots. This outcome results from limited funds or from spatially inefficient buyouts that create a patchwork pattern of open space, rather than contiguous open space (Zavar and Hagelman 2016). Some residents consider grassy lots a "waste," whereas others view the same lots as an informal "park" (Zavar 2015). Furthermore, large and continuous areas of open space are more effective at reducing flood losses than patchworks of houses and open lots (Brody et al. 2017). Those who stay behind face a changed neighborhood with potential for loss of community, sense of place, and social capital, which may affect those who live in areas adjacent to where buyouts were offered (Binder et al. 2015, 2019, 2020).

Buyout programs also affect the wider community in which the buyouts took place. The budget of the jurisdiction will likely be affected through a reduction in the number of properties contributing to local property tax revenues (BenDor et al. 2020; Shi and Varuzzo 2020), and significant costs can be associated with the maintenance of buyout lots (Zavar 2015). It is unclear whether and how much property values near the newly open spaces increase or whether new construction of replacement housing can make up for this loss in local budget. Furthermore, there are significant legal implications for jurisdictions who would like to reduce costs by limiting maintenance and services in neighborhoods where many of the households have left (Ruppert et al. 2019).

\section{Destination communities}

There is no existing literature on destination communities receiving households that relocated through a buyout program, which inhibits assessment of equity and social justice. Case studies looking into post-buyout relocations in Houston, TX (Loughran and Elliott 2019), and New York City, NY (McGhee et al. 2020), indicate that many households remained nearby after they sold their homes through buyouts. This aligns with preferences indicated in other locations (Bukvic and Owen 2017). However, post-disaster migration has also included large-scale out-of-state movement. Many New Orleans residents relocated to other counties in Louisiana, but large numbers also migrated to Houston, TX, after Hurricane Katrina (Eyer et al. 2018). When Puerto Ricans moved in large numbers to Orlando, FL, after Hurricane Maria, employment and high school attendance both increased in the area (Meléndez et al. 2017; Peri et al. 2020). Future buyouts might need to take place at greater scale than has happened historically, intensifying effects on destination communities. Associated migration flows could result in new economic and social opportunities for the destination communities to which the buyout households relocate but also place more pressure on limited resources, such as housing, healthcare, schools, and social services. 


\section{Strategies to promote equity in buyout programs}

In this section, we discuss policy options that have the potential to mitigate the equity concerns raised in the "Equity and social justice issues in voluntary property buyout programs" section, using the same stakeholder categories. These strategies are relevant to different actors: funding agencies who provide resources to finance buyouts; implementers, usually local governments, who lead and administer buyout programs; and local governments of destination communities. An overview of all strategies, the relevant actor, and the relevant equity and justice concerns can be found in Table 1 . The policy options outlined in this section may improve equity outcomes for future buyout programs (Fig. 1).

\section{Communities in which buyouts may occur}

Use funding to invest in administrative capacity and program evaluation Higher-level government, including states and federal agencies like FEMA and HUD, could use funding to enable more equitable access to buyout programs. They can support local-government buyout program administrators through long-term capacity building, e.g., through investment in the staffing, knowledge, and skills necessary to implement buyout programs that are fair in their availability for residents (Table 1, strategy 1). Investment in local capacity to implement buyouts could reduce barriers to participation for communities with limited financial and human resources (Kick et al. 2011). Buyout funders could also incentivize better reporting of where buyouts are offered, who accepts buyout offers, and participants' relocation destinations (McGhee et al. 2020). They could set requirements for monitoring and reporting on buyout projects, similar to the Home Mortgage Disclosure Act (Table 1, strategy 2). Better data collection could improve understanding of program outcomes and enhance assessment of equity in buyout programs.

\section{Potential participants and relocating households}

Increase community engagement and support Residents perceive buyouts as more equitable when they are actively involved in the design phase and decision-making in buyout programs (Baker et al. 2018; Kick et al. 2011). This includes the question of whether buyouts are the appropriate flood mitigation option for a community. Involving residents in the buyout process from the start has proven successful in multiple relocation programs (Binder and Greer 2016; Fraser et al. 2003; Siders 2019; Table 1, strategy 3). More transparency in decision-making could improve trust between buyout communities and implementing officials (Baker et al. 2018; Binder and Greer 2016; Siders 2019), for example, through clear communication of rationales for why certain areas are included or excluded from the program (Table 1, strategy 4). Trust could also be increased by providing residents with consistent professional support in navigating the buyout process (De Vries and Fraser 2012; Fraser et al. 2003; Table 1, strategy 5). Such counselors have been most effective when they were already working in the buyout neighborhood, were well-trained, and were included in the process by the implementer (Fraser et al. 2003). A designated point of contact at the implementer level, rather than requiring interaction with a different government official in each communication, has been suggested by buyout program participants to avoid miscommunication and improve clarity (Baker et al. 2018; Kick et al. 2011; Table 1, strategy 6).

For households moving out of their origin community, relocation assistance and coordination between local governments could ease the transition in some contexts (Flanigan 2019). For example, relocation counselors could help identify safe, affordable locations to which participating households could move or areas with promising job opportunities, social services, or schools (Table 1, strategy 5). Once a household is ready to relocate, the bureaucratic burden on households could be reduced, for instance, through automatic transfer of children's records between school districts (Table 1, strategy 7). These strategies have not been widely tested in buyout programs, but could be employed during the buyout implementation phase and, in support of households in the buyout process, present potential opportunities to promote experiences of interactional justice.

Expedite the buyout process with care Slow buyout processes exacerbate emotional and financial stress. Fast buyout processes could place pressure on residents who are unsure whether or not they wish to accept a buyout, so speed should not come at the expense of a meaningful deliberation process (De 2017; De Vries and Fraser 2012). However, once residents have decided to relocate, the timeline from decision to execution should be accelerated. Faster implementation of buyouts could be accomplished by using National Flood Insurance Program (NFIP) claim payouts as compensation to the homeowner wherever this amount equals the (pre-disaster) property value (Weber and Moore 2019; Table 1, strategy 8). For homes that are located in the floodplain and substantially damaged, the Increased Cost of Compliance (ICC) coverage of $\$ 30,000$ could be used if assessed damages are less than the pre-disaster property value (FEMA 2017; Weber and Moore 2019). Offering buyouts immediately after a disaster might increase the uptake of buyouts and therefore limit the checkerboard pattern of buyouts that has often occurred. Potential subtractions from the final buyout offer based on FEMA's duplication-of-benefits policy would be avoided if the resident is given the opportunity of a buyout before expenses are accrued to repair the damaged home. Steps can also be taken to expedite the buyout process if other sources of funding are 
Table 1 Strategies for addressing equity and social justice dimensions of voluntary buyouts. Equity concerns have surfaced in the implementation and outcomes of voluntary property buyouts. Strategies to improve equity are presented for affected resident groups, listing the relevant actors. Buyout implementers are most often local governments
Strategy
Relevant actor
Equity concern addressed (social justice dimension)

Communities in which buyouts may occur

1 Investment in buyout implementation capacity at state, Funders local, and funding levels (Kick et al. 2011)

2 Buyout funding includes monitoring and reporting requirements (McGhee et al. 2020)

Potential participants and relocating households

3 Involve residents in buyout process from the start (Baker et al. 2018; Binder and Greer 2016; Fraser et al. 2003; Siders 2019)

4 Increase transparency in decision-making (Baker et al. 2018; Binder and Greer 2016; Siders 2019)

5 Provide homeowners with professional support in navigating through buyout process (De Vries and Fraser 2012; Fraser et al. 2003)

6 Provide a designated point of contact for residents (Baker et al. 2018; Kick et al. 2011)

7 Reduce bureaucratic burden on relocating households (Flanigan 2019)

8 Allow NFIP damage claim plus ICC to be used for rapid buyout (Weber and Moore 2019)

9 Revision of duplication-of-benefits policy (Baker et al. 2018; Binder and Greer 2016)

10 Compensating homeowners based on replacement value, including moving expenses (Baker et al. 2018; HUD 2019)

Households remaining in buyout communities

11 Require post-buyout land use plan as part of community hazard mitigation planning and/or floodplain management (Zavar 2015)

12 Consider ecological value of the resulting open space when Implementers deciding to make buyout offer (Atoba et al. 2020)

13 Including costs for post-buyout land use in program funding Funders (Zavar and Hagelman 2016)

14 Using targeted buyouts to invest in underserved neighborhoods (Wolch et al. 2014)

15 Land ownership held by non-profit organizations with con- Implementers servation or community goals (Weber and Moore 2019)

Destination communities

16 Developing affordable housing and other social services (Been et al. 2018; Forsyth and Peiser 2020)
Funders

Implementers

Implementers

Implementers

Implementers

Implementers and Frustration over buyout process (interactional) destination communities

FEMA

FEMA

Funders (esp. FEMA)

Funders

Suboptimal use of open space (distributive)

Suboptimal use of open space, loss of sense of community/place (distributive)

Suboptimal use of open space, loss of sense of community/place (distributive)

Implementers and Lack of open space (distributive), also related to unequal access to buyout programs

Suboptimal use of open space, loss of sense of community, and community self-determination (distributive, procedural)

Destination communities
Lack of affordable housing, prevent undue pressure on social services (distributive) used, such as FEMA's Hazard Mitigation Grant Program or HUD's Community Development Block Grant-Disaster Recovery, to avoid inequality between those who are able to afford flood insurance and those who are not.

In jurisdictions where residents voice a demand for buyouts, proactive planning for buyouts to take place after the next disaster could help shorten the duration of the process once disaster funding becomes available. However, a government-initiated buyout program may not be the preferred option in all cases. In some communities, residents have found empowerment in initiating buyouts (Koslov 2016). Another option is finding alternative sources of funding for buyouts, independent from disasters. Charlotte-Mecklenburg, $\mathrm{NC}$, has been successful in leveraging local storm water fees to complete buyouts within 6 months after a flood (Weber and Moore 2019). 
Expanding compensation for buyout-related costs For some households, typical buyout compensation may not be sufficient to enable them to move to a satisfactory location, and adjusting compensation based on need could improve both participation and relocation outcomes. Buyouts could be a more attractive and feasible option for households if federal assistance used for necessary repairs made before the buyout were not subtracted from the final compensation (Baker et al. 2018; Binder and Greer 2016; Table 1, strategy 9), or if buyout programs were implemented sooner after the disaster such that repair is not necessary.

Additionally, compensating homeowners based on replacement value as per the Uniform Relocation Assistance and Real Property Acquisition Act (URA), rather than predisaster fair market value, could help expand the choice set for relocating residents, including lower flood-risk locations (Baker et al. 2018; Table 1, strategy 10). FEMA allows implementers to add an additional $\$ 31,000$ - the so-called shortfall - to the fair market value if the cost of a comparable home outside the flood zone is higher (FEMA 2015). The URA aims to provide a more comprehensive replacement value through the additional inclusion of mortgage-interest differential payment and moving expenses, including mortgage and closing costs (HUD 2019). For example, if property compensation is insufficient to find a new house with comparable characteristics and community, relocating households may face challenges such as needing to move further away or downsize, and stress associated with relocation could be increased or relocation may not occur at all. Conversely, adequate financial and structural support may help households perceive and experience the buyout as an opportunity to improve their wellbeing.

Some buyout programs have provided additional incentives under certain circumstances. Such incentives can expand the choice set for residents, but they should be applied wisely. Monetary incentives to nudge entire blocks to accept buyout offers, with the aim to reduce inefficient land use post-buyout, have been implemented but quickly withdrawn as they caused tensions among neighbors who felt intimidated into participation (Baker et al. 2018).

\section{Households remaining in buyout communities}

Budget and plan for open space land use Appropriate land use of buyout sites leads to better outcomes for residents that remain in buyout communities (Zavar 2015). Effective use of open space resulting from buyouts could be supported by developing long-term plans for post-buyout land use and management during the design phase of the buyout program, which could be incentivized by funders (Zavar 2015; Table 1, strategy 11). Funders could also require indications of the long-term land use (maintenance) plan in the implementer's application for buyout grants. In the selection of parcels to offer buyouts, implementers could also consider the ecological value of properties to optimize flood attenuation and environmental quality (Atoba et al. 2020; Table 1, strategy 12). Creating a clear vision for the land post-buyout could improve its flood risk mitigation potential and the amenities for nearby residents. On Staten Island, NY, households reported feeling incentivized to participate in the buyout program in order to serve a greater goal (Baker et al. 2018). Involvement of residents helps ensure land use planning aligns with community desires and avoids disused open space (Zavar 2015). Buyout funders could consider granting money for designing and creating post-buyout land uses that are beneficial to the community, such as a park, athletic facilities, or playground (Table 1, strategy 13).

Open space can positively impact neighborhoods when designed and maintained appropriately (e.g., Douglas et al. 2017; Loughran 2018). Buyouts could also be used as a way to invest in historically marginalized and underserved communities (Table 1, strategy 14). For example, lands could be used to build parks in historically redlined neighborhoods, which on average are hotter and have less green space (Hoffman et al. 2020; Wolch et al. 2014). As significant improvements in amenities can also result in displacement and gentrification, aiming for "just green enough" might be most helpful to residents remaining in buyout communities, although this will require careful design and evaluation (Wolch et al. 2014). State and federal governments could help communities gain access to buyout program funding and provide support for land maintenance after acquisition (Table 1, strategy 1 \& 13). Alternatively, allowing community groups or conservation organizations to take over management or ownership of the land could reduce maintenance costs for local government and help use the land in ways that support the community (Weber and Moore 2019; Table 1, strategy 15).

\section{Destination communities}

Prepare to receive relocating households Local governments that want to incentivize buyout participants to stay local or to move into their communities could make sure infrastructure and social services are available and accessible (Table 1, strategy 16). Availability of affordable housing is a particular concern. Much has been written about this in the housing policy literature (e.g., Been et al. 2018; Ortiz and Johannes 2018). In order to facilitate relocation support, buyout funders could require that replacement housing will be built outside of the floodplain. In rural Princeville, NC, nearby public land has been annexed, as higher ground within the jurisdiction was limited (Adaptation Clearinghouse 2020). For dense jurisdictions where new building is difficult, agreements could be put in place with neighboring jurisdictions to accommodate relocating residents. Comprehensively planned new 
settlements could also be destinations for buyout participants. Lessons for such communities can draw from planned relocation and new town experiences (Forsyth and Peiser 2020).

\section{Data collection and evaluation}

Although different distributive, procedural, and interactional justice concerns have been raised about buyout programs, assessment of equity issues is limited by a lack of information about how buyout program design and implementation affect outcomes for those that consider participation. Below, we first shine light on some of these knowledge gaps that exist. We then present ways in which improved data collection and accessibility can help fill these gaps and further enhance buyout programs (Fig. 1).

\section{Knowledge gaps}

Deeper understanding of the short- and long-term impacts of buyouts on affected households and communities is necessary for more fully evaluating and promoting distributive justice. Despite the fact that buyouts have been implemented for more than 30 years and affected tens of thousands of households, there is limited evidence about the impacts and outcomes of buyout programs for the different stakeholder groups discussed above: do relocating households gain access to improved economic and educational opportunities? Do remaining households maintain strong social ties and benefit from new open space? A few programmatic or nationwide analyses of where buyouts have occurred have been performed (Elliott et al. 2020; Mach et al. 2019; Weber and Moore 2019; Zavar and Hagelman 2016), but no national review of outcomes exists. Efforts to improve future program outcomes are hampered by the sparse evidence on where participants relocate, and how the buyouts have affected their financial, physical, and emotional well-being. Limited insight also exists into how buyouts impact social cohesion, property values, and neighborhood satisfaction in buyout communities (Binder et al. 2015, 2019).

Buyout program design and implementation, and its associated procedural and interactional justice dimensions, likely shape outcomes for residents and communities. As a result of local priorities and constraints, choices in program design and implementation result in widely varying goals, incentives, and practices across different buyout programs (De Vries and Fraser 2012; Koslov 2016; Siders 2019). In-depth case studies have taken place for some of the larger buyout programs, e.g., in Staten Island, NY (Baker et al. 2018; Binder and Greer 2016; Koslov 2016), Houston, TX (Loughran and Elliott 2019; Loughran et al. 2019), or Cedar Rapids, IA (Muñoz and Tate 2016; Tate et al. 2016). However, there are 100 jurisdictions across the USA that have bought out more than
100 properties (Mach et al. 2019), and evaluation of most of these programs is sparse or nonexistent. As a result, very little is known about the impacts of buyout program design and implementation on how different households experience the buyout process. Comparative case studies of buyout program design and implementation might improve our understanding of which programs yield best results.

Another obstacle to understanding social justice is lack of documentation. Only completed buyouts are documented, while inequities can emerge at many stages, including in decisions not to participate. Local governments decide whether or not to apply for buyout funds and which houses are eligible, within the constraints of funding sources. Homeowners decide whether or not to apply in some jurisdictions. Then, costbenefit analyses, total amount of funding available, and other priorities determine which households are offered a buyout, as well as what resources are provided in the relocation of the households who accept their offers (FEMA 2015; Mach et al. 2019). Understanding household participation throughout these stages would enable researchers to distinguish between households not having access to buyout programs and households who had the option, but chose not to participate.

\section{Data reporting for buyout program evaluation}

Better data collection and reporting on process and outcomes could enable evaluation of linkages among buyout-program design, implementation processes, and longer-term impacts for participating property owners and remaining residents. These analyses could be used to determine best practices and develop additional strategies to promote equity in buyout programs. In order to facilitate data collection on local buyout programs, we suggest several relevant indicators in Table 2 . We have focused on indicators that implementers could reasonably collect and report on during the buyout process. Some indicator data are already available to implementers, such as funding sources, eligibility requirements, and participation data and simply would need to be documented during the buyout process. Other indicator data are not currently available but could be collected from (potential) participants through application forms or post-buyout surveys. Reporting requirements from funders could increase implementation of data collection (see also Table 1, strategy 2).

The indicators presented in Table 2 can bring more insight into buyout program details and outcomes, which could generate more strategies to improve distributive justice in buyout programs. Household-specific indicators, such as income level and self-reported race or ethnicity, can help researchers understand who is participating and their needs. The location of the buyout property and the relocation address could be combined with flood risk data or US Census Bureau statistics. This could yield insight into whether participants have been able to reduce their 
Table 2 Indicators for monitoring and evaluating the impacts and outcomes of buyout programs. Standardization and compilation of indicators collected by different programs facilitate program evaluation, cross-cutting analysis, and policy learning. Indicator metrics listed here draw from data available to the implementer, unless marked by ${ }^{*}$, in which case data collection from households is necessary

\begin{tabular}{|c|c|}
\hline Indicator category & Specific indicator metrics \\
\hline Administration and design process & $\begin{array}{l}\text { Type of administrator (e.g., town/city, county, state, special district) } \\
\text { Funding sources } \\
\text { Funding requirements and constraints }\end{array}$ \\
\hline Neighborhood targeted for buyouts & $\begin{array}{l}\text { Location of neighborhood } \\
\text { Rationale for inclusion in buyout program }\end{array}$ \\
\hline Buyout program details & $\begin{array}{l}\text { Conditions and limitations of participation in program } \\
\text { Rebuilding restrictions (post-disaster) } \\
\text { Compensation and incentives } \\
\text { Other sources of support }\end{array}$ \\
\hline Post-buyout land use planning & $\begin{array}{l}\text { Goals for post-buyout land use of buyout properties } \\
\text { Funding availability for post-buyout land use plan }\end{array}$ \\
\hline Household-level data about homeowners who apply & $\begin{array}{l}\text { Household income* } \\
\text { Race/ethnicity* } \\
\text { Housing tenure* } \\
\text { Eligibility to participate in program } \\
\text { Acceptance or refusal of offer* } \\
\text { Reasons for refusal of offer* }\end{array}$ \\
\hline Property data about properties who receive buyout offers & $\begin{array}{l}\text { Address } \\
\text { Assessed property value (pre-disaster) } \\
\text { Damage category } \\
\text { Repetitive Loss or Severe Repetitive Loss status } \\
\text { Parcel size }\end{array}$ \\
\hline Participation data & $\begin{array}{l}\text { Number of applications } \\
\text { Number of offers extended } \\
\text { Offer acceptance rate } \\
\text { Dates of applications } \\
\text { Dates of offers extended }\end{array}$ \\
\hline Outcomes for each relocating household & $\begin{array}{l}\text { Date of close of property sale* } \\
\text { New address* } \\
\text { Date of new property purchase or start of lease* } \\
\text { Housing tenure at new address (purchase or lease)* } \\
\text { Sale price of new property or rent price of new lease* }\end{array}$ \\
\hline Outcomes for remaining community & $\begin{array}{l}\text { Demolition date for each property } \\
\text { Date land use plan implemented } \\
\text { Land use plan implementation cost } \\
\text { Estimated maintenance cost }\end{array}$ \\
\hline
\end{tabular}

flood risk, and if they moved into socioeconomically and demographically comparable neighborhoods. If a household moved from an owner-occupied unit to a long-term rental-e.g., due to lack of affordable properties, as has been reported in Baker et al. (2018) - this transition could indicate different impacts than if the household were able to purchase another property. Data about participation and program details can help researchers assess buyout program designs that are more successful at equitably removing households from the floodplain.

Aspects of procedural and interactional justice are less straightforward to operationalize or quantify and are consequently not as prominent in Table 2 . In order to analyze how procedural and interactional justice can be promoted in buyout programs, more qualitative, in-depth research into community engagement, communication, and participant experiences is needed. Some information about buyout process experiences could be collected through the same post-buyout surveys of participants as those used to confirm relocation addresses.

The impacts of buyout programs can be evaluated by policy analysists or academic researchers when relevant data are not just collected but made accessible. An effective system of data reporting and evaluation for buyouts should span scales. Improved data reporting is required at the local level of implementation. At state, federal agency, or overall national levels, databases of collected data could support integrative and cross-cutting analyses, as well as knowledge transfer across locations, levels of government, and other relevant actors including non-governmental organizations and the private 
sector. Privacy of sensitive household-level data is also a social justice concern. Privacy concerns can be mitigated by storing datasets about specific buyout programs and national collections of buyout program data in a secure manner and limiting access to sensitive data. Ethical requirements and privacy safeguards are especially important when using household-level data with origin and destination addresses, incomes, etc. Procedures to protect similarly sensitive data are already in place at the US Census Bureau, which makes restricted-use microdata available only to qualified researchers through Federal Statistical Research Data Centers. Data with lower sensitivity to privacy concerns, such as census-tract level summary information about buyouts, could be made more readily available, preferably in an open-access format.

\section{Conclusion}

Evaluations of buyout programs have raised a number of social justice issues, ranging from distributive, to procedural, to interactional justice. In this policy analysis, we have discussed those concerns for four stakeholder groups: the wider communities in which buyouts may occur, potential participants and relocating households, households remaining in the buyout community, and destination communities. We have presented a number of strategies that buyout funders and implementers could apply in practice to promote equity in some contexts (Table 1). Many of these proposed strategies have yet to be evaluated. More broadly, little information is available about the outcomes of buyout programs, limiting evaluation of the links between buyout program design, implementation, and outcomes. We have also suggested a short list of indicators that could reasonably be expected to be collected by buyout administrators (Table 2). Data on buyout and relocation addresses, program incentives, and post-buyout land use could help analysts and researchers improve understanding of the impacts of buyout programs on residents, help funders to create improved funding guidelines, and allow for the identification of potential federal interventions where locally administered buyouts fall short, such as in contexts where community relocation might be more appropriate (GAO 2020).

There is no single best way to design and implement voluntary property buyout programs across the many US communities where buyouts are needed at present or in the future. Tradeoffs will need to be made between competing goals and interests, while meeting funding requirements with limited resources. Not all of the strategies that we have presented here will work in all contexts. Strategies to improve outcomes for one stakeholder group can sometimes have unforeseen consequences for others. This policy analysis aims to bring practical policy options to the conversation on how to facilitate managed retreat through equitable voluntary property buyouts. Buyouts might never be perfect, but they can be better.
Funding The research was supported by the Rosenstiel School of Marine and Atmospheric Science and the Leonard and Jayne Abess Center for Ecosystem Science and Policy, University of Miami.

\section{Declarations}

Competing interests The authors declare no competing interests.

Open Access This article is licensed under a Creative Commons Attribution 4.0 International License, which permits use, sharing, adaptation, distribution and reproduction in any medium or format, as long as you give appropriate credit to the original author(s) and the source, provide a link to the Creative Commons licence, and indicate if changes were made. The images or other third party material in this article are included in the article's Creative Commons licence, unless indicated otherwise in a credit line to the material. If material is not included in the article's Creative Commons licence and your intended use is not permitted by statutory regulation or exceeds the permitted use, you will need to obtain permission directly from the copyright holder. To view a copy of this licence, visit http://creativecommons.org/licenses/by/4.0/.

\section{References}

Adaptation Clearinghouse (2020) Annexing and preparing higher ground receiving areas in Princeville, North Carolina through post-disaster recovery processes. https://www.adaptationclearinghouse.org/ resources/annexing-and-preparing-higher-ground-receiving-areasin-princeville-north-carolina-through-post-disaster-recoveryprocesses.html. Accessed December 152020

Adger WN, Paavola J, Huq S, Mace MJ (2006) Fairness in adaptation to climate change. MIT Press, Cambridge, MA

Atoba KO, Brody SD, Highfield WE, Shepard CC, Verdone LN (2020) Strategic property buyouts to enhance flood resilience: a multicriteria spatial approach for incorporating ecological values into the selection process. Environ Hazards 22:1-19. https://doi.org/10. 1080/17477891.2020.1771251

Baker CK, Binder SB, Greer A, Weir P, Gates K (2018) Integrating community concerns and recommendations into home buyout and relocation policy risk. Hazards Crisis Public Policy 9:455-479. https://doi.org/10.1002/rhc3.12144

Been V, Ellen IG, O'Regan K (2018) Supply skepticism: housing supply and affordability. Hous Policy Debate 29:29-40. https://doi.org/10. 1080/10511482.2018.1476899

BenDor TK, Salvesen D, Kamrath C, Ganser B (2020) Floodplain buyouts and municipal finance. Nat Hazards Rev 21:04020020. https:// doi.org/10.1061/(asce)nh.1527-6996.0000380

Binder SB, Greer A (2016) The devil ss in the details: linking home buyout policy, practice, and experience after Hurricane Sandy. Polit Governance 4:97-106. https://doi.org/10.17645/pag.v4i4.738

Binder SB, Baker CK, Barile JP (2015) Rebuild or relocate? Resilience and postdisaster decision-making after Hurricane Sandy. Am J Community Psychol 56:180-196. https://doi.org/10.1007/s10464015-9727-X

Binder SB, Barile JP, Baker CK, Kulp B (2019) Home buyouts and household recovery: neighborhood differences three years after Hurricane Sandy. Environ Hazards 18:127-145. https://doi.org/10. 1080/17477891.2018.1511404

Binder SD, Ritchie LA, Bender R, Thiel A, Baker CK, Badillo E, Goodfellow S, Kulp B, Weir P (2020) Limbo: the unintended consequences of home buyout communities on peripheral communities. Environ Hazards 19:488-507. https://doi.org/10.1080/17477891. 2020.1714537 
Braamskamp A, Penning-Rowsell EC (2018) Managed retreat: a rare and paradoxical success, but yielding a dismal prognosis. Environ Manag Sustain Dev 7:108. https://doi.org/10.5296/emsd.v7i2. 12851

Brody SD, Highfield WE, Blessing R, Makino T, Shepard CC (2017) Evaluating the effects of open space configuations in reducing flood damage along the Gulf of Mexico coast. Landsc Urban Plan 167: 225-231. https://doi.org/10.1016/j.landurbplan.2017.07.003

Bukvic A, Owen G (2017) Attitudes towards relocationg following Hurricane Sandy: should we stay or should we go? Disasters 41: 101-123. https://doi.org/10.1111/disa.12186

Bullard RD, Johnson GS (2000) Environmental justice: grassroots activism and its impacts on public policy making decisions. J Soc Issues 56:555-578

De Vries (2017) Temporal vulnerability and the post-disaster 'window of opportunity to woo:' a case study of an African-American floodplain neighborhood after Hurricane Floyd in North Carolina. Hum Ecol 45:437-448

De Vries DH, Fraser JC (2012) Citizenship rights and voluntary decision making in post-disaster U.S. floodplain buyout mitigation programs. Int J Mass Emerg Disasters 30:1-33

Douglas O, Lennon M, Scott M (2017) Green space benefits for health and well-being: a life course approach for urban planning, design and management. Cities 66:53-62. https://doi.org/10.1016/j.cities. 2017.03.011

Elliott JR, Brown PL, Loughran K (2020) Racial inequities in the federal buyout of flood-prone homes: a nationwide assessment of environmental adaptation. Socius 6:237802312090543. https://doi.org/10. $1177 / 2378023120905439$

Eyer J, Dinterman R, Miller N, Rose A (2018) The effect of disasters on migration destinations: evidence from Hurricane Katrina. Econ Disasters Clim Change 2:91-106. https://doi.org/10.1007/s41885017-0020-3

FEMA (2012) Hazard Mitigation Assistance (HMA) tool for identifying duplication of benefits: hazard migitation grant program, predisaster mitigation program, and flood mitigation assistance program. https://www.fema.gov/media-library-data/201307261901-25045-3291/duplication_of_benefits_guide_2013.pdf. Accessed December 152020

FEMA (2015) Hazard mitigation assistance guidance addendum: hazard migitation grant program, pre-disaster mitigation program, and flood mitigation assistance program. https://www.fema.gov/sites/default/ files/2020-07/fy15_HMA_Guidance.pdf. Accessed December 15 2020

FEMA (2017) National flood insurance program: answers to frequently asked questions about increased cost of compliance. https://www. fema.gov/sites/default/files/2020-11/fema_p1080_icc_faq 20170817.pdf. Accessed December 152020

FEMA (2020) OpenFEMA dataset: hazard mitigation assistance mitigated properties - v2. https://www.fema.gov/openfema-data-page/ hazard-mitigation-assistance-mitigated-properties-v2. Accessed December 152020

Flanigan ST (2019) Diverging from "bureaucracy": A case study of organizational image in housing services. J Public Manag Soc Policy 26:3-20

Folger R (1996) Distributive and procedural justice: multifaceted meanings and interrelations. Soc Justice Res 9:395-416

Forsyth A, Peiser R (2020) Lessons from planned resettlement and new town experiences for avoiding climate sprawl. Landsc Urban Plan 205:103957. https://doi.org/10.1016/j.landurbplan.2020.103957

Fraser JC, Elmore R, Godschalk D, Rohe W (2003) Implementing floodplain land acquisition programs in urban localities. The Center for Urban and Regional Studies. University of North Carolina at Chapel Hill, Chapel Hill, NC

GAO (2020) Climate change: A climate change migration pilot program could enhance the nation's resilience and reduce federal fiscal exposure vol GAO-20-488. U.S. Government Accountability Office, Washington, DC

Gotham KF (2014) Reinforcing inequalities: the impact of the CDBG program on post-Katrina rebuilding. Hous Policy Debate 24:192212. https://doi.org/10.1080/10511482.2013.840666

Green TF, Olshansky RB (2012) Rebuilding housing in New Orleans: the Road Home Program after the Hurricane Katrina disaster. Hous Policy Debate 22:75-99. https://doi.org/10.1080/10511482.2011. 624530

Greer A, Binder S (2017) A historical assessment of home buyout policy: are we learning or just failing? Hous Policy Debate 27:372-392. https://doi.org/10.1080/10511482.2016.1245209

Hauer ME, Evans JM, Mishra DR (2016) Millions projected to be at risk from sea-level rise in the continental United States. Nat Clim Chang 6:691-695. https://doi.org/10.1038/nclimate2961

Hoffman JS, Shandas V, Pendleton N (2020) The effects of historical housing policies on resident exposure to intra-urban heat: a study of 108 US urban areas. Climate 8:12. https://doi.org/10.3390/ cli8010012

HUD (2019) Tenant assistance, relocation and real property acquisition handbook 1378. Accessed at: https://www.hud.gov/program offices/administration/hudclips/handbooks/cpd/13780. Accessed December 152020

Jay A et al (2018) Overview. In: Reidmiller DR, Avery CW, Easterling DR, Kunkel KE, Lewis KLM, Maycock TK, Stewart BC (eds) Impacts, risks, and adaptation in the United States: Fourth National Climate Assessment, vol II. U.S. Global Change Research Program, Washington, DC, USA, pp 33-71. https://doi. org/10.7930/NCA4.2018.CH1

Kick EL, Fraser JC, Fulkerson GM, McKinney LA, De Vries DH (2011) Repetitive flood victims and acceptance of FEMA mitigation offers: an analysis with community-system policy implications. Disasters 35:510-539. https://doi.org/10.1111/j.1467-7717.2011.01226.x

Koslov L (2016) The case for retreat. Publ Cult 28:359-387. https://doi. org/10.1215/08992363-3427487

Lincke D, Hinkel J (2018) Economically robust protection against $21^{\text {st }}$ century sea-level rise. Glob Environ Chang 51:67-73. https://doi. org/10.1016/j.gloenvcha.2018.05.003

Loughran K (2018) Urban parks and urban problems: a historical perspective on green space development as cultural fix. Urban Stud 57: 2321-2338. https://doi.org/10.1177/0042098018763555

Loughran K, Elliott JR (2019) Residential buyouts as environmental mobility: examining where homeowners move to illuminate social inequities in climate adaptation. Popul Environ 41:52-70. https://doi. org/10.1007/s11111-019-00324-7

Loughran K, Elliott JR, Kennedy SW (2019) Urban ecology in the time of climate change: Houston, flooding, and the case of federal buyouts. Soc Curr 6:121-140. https://doi.org/10.1177/2329496518797851

Mach KJ, Kraan CM, Hino M, Siders AR, Johnston EM, Field CB (2019) Managed retreat through voluntary buyouts of flood-prone properties. Sci Adv 5:eaax8995. https://doi.org/10.1126/sciadv.aax8995

Marino E (2018) Adaptation privilege and voluntary buyouts: perspectives on ethnocentrism in sea level rise relocation and retreat policies in the US. Glob Environ Chang 49:10-13. https://doi.org/10.1016/j. gloenvcha.2018.01.002

Martin A (2019) Race, place, and resilience: social equity in North Carolina's post-disaster buyout program. Dissertation, University of North Carolina at Chapel Hill. https://doi.org/10.17615/gkjb6503

McGhee DJ, Binder SB, Albright EA (2020) First, do no harm: evaluating the vulnerability reduction of post-disaster home buyout programs. Nat Hazards Rev 21:21. https://doi.org/10.1061/(ASCE) NH.1527-6996.0000337

Meléndez E, Hinojosa J, Roman N (2017) Post-hurricane Maria exodus from Puerto Rico and school enrollment in Florida. Centro Center 
for Puerto Rican Studies, City University of New York, New York, NY

Muñoz C, Tate E (2016) Unequal recovery? Federal resource distribution after a Midwest flood disaster. Int J Environ Res Public Health 13: 507. https://doi.org/10.3390/ijerph13050507

Ortiz SE, Johannes BL (2018) Building the case for housing policy: understanding public housing affordability as a key social determinant of health. SSM - Popul Health 6:6-71. https://doi.org/10.1016/ j.ssmph.2018.08.008

Peri G, Rury D, Wiltshire J (2020) The economic impact of migrants from Hurricane Maria. IZA Institute of Labor Economics, Bonn, Germany

Phillips B, Stukes PA, Jenkins P (2012) Freedom Hill is not for sale - and neither is the Lower Ninth Ward. J Black Stud 43:405-426. https:// doi.org/10.1177/0021934711425489

Purdy B (2019) Planning and design scenarios for equitable outcomes in managed retreat. Master's Thesis, Massachusetts Institute of Technology. https://dspace.mit.edu/handle/1721.1/123932. Accessed December 152020

Rawls J (1971) A Theory of Justice. Harvard University Press, Cambridge, MA

Robinson CS, Davidson RA, Trainor JE, Kruse JL, Nozick LK (2018) Homeowner acceptance of voluntary property acquisition offers. Int J Disaster Risk Reduction 31:234-242. https://doi.org/10.1016/j. ijdrr.2018.05.002

Ruppert T, Deady EL, Evans JM, Goodison C (2019) Legal issues when managing public roads affected by sea level rise. SSRN, Florida. https://doi.org/10.2139/ssrn.3441438

Schlosberg D (2012) Climate justice and capabilities: a framework for adaptation policy. Ethics Int Aff 26:445-461. https://doi.org/10. 1017/S0892679412000615

Schlosberg D, Collins LB (2014) From environmental to climate justice: climate change and the discourse of environmental justice. WIREs Clim Change 5:359-374. https://doi.org/10.1002/wcc.275
Shi L, Varuzzo AM (2020) Surging seas, rising fiscal stress: Exploring municipal fiscal vulnerability to climate change. Cities 100:102658. https://doi.org/10.1016/j.cities.2020.102658

Shue H (1992) The Unavoidability of Justice. In: Hurrell A, Kingsbury B (eds) The International Politics of the Environment. Oxford University Press, Oxford, UK, pp 373-397

Siders AR (2019) Social justice implications of US managed retreat buyout programs. Clim Chang 152:239-257. https://doi.org/10.1007/ s10584-018-2272-5

Tate E, Strong A, Kraus T, Xiong H (2016) Flood recovery and property acquisition in Cedar Rapids. Iowa Nat Hazards 80:2055-2079. https://doi.org/10.1007/s11069-015-2060-8

Thomas J (2019) A win-lose situation: exploring the impacts of floodplain buyouts on participants in Illinois. Master's Thesis, University of Illinois at Urbana-Champaign. https://www.ideals.illinois.edu/ bitstream/handle/2142/106005/Thomas_Jasmine-Report.pdf? sequence $=2 \&$ isAllowed $=y$. Accessed December 152020

Weber A, Moore R (2019) Going under: long wait times for post-flood buyouts leave homeowners underwater. Natural Resources Defense Council, Washington, DC

Wolch JR, Byrne J, Newell JP (2014) Urban green space, public health, and environmental justice: the challenge of making cities 'just green enough'. Landsc Urban Plan 125:234-244. https://doi.org/10.1016/ j.landurbplan.2014.01.017

Zavar E (2015) Residential perspectives: the value of floodplain-buyout open space. Geogr Rev 105:78-95. https://doi.org/10.1111/j.19310846.2014.12047.x

Zavar E, Hagelman RRI (2016) Land use change on U.S. floodplain buyout sites, 1990-2000. Disaster Prev Manag 25:360-374. https://doi.org/10.1108/DPM-01-2016-0021

Publisher's Note Springer Nature remains neutral with regard to jurisdictional claims in published maps and institutional affiliations. 